\title{
Impact of Exposure to Low Temperature Degrees in Field Conditions on Leaf Pigments and Chlorophyll Fluorescence in Leaves of Mango Trees
}

\author{
Ali A.S. Sayed ${ }^{1, a}$, Farouk M. Gadallah ${ }^{1, b}$, Mohamed A. Seif El-Yazal ${ }^{1, c}$, \\ Gamal A. Abdel-Samad ${ }^{2, d}$ \\ ${ }^{1}$ Botany Department, Faculty of Agriculture, Fayoum University, Fayoum 63514, Egypt. \\ ${ }^{2}$ Horticulture Department, Faculty of Agriculture, Fayoum University, Fayoum 63514, Egypt. \\ aaas10@Fayoum.edu.eg, b fmg00@ Fayoum.edu.eg, c mas04@ Fayoum.edu.eg, \\ 'gaa00@Fayoum.edu.eg
}

Keywords: Mango, Cultivars, Cold Tolerance, leaf pigments, chlorophyll fluorescence

\begin{abstract}
This experiment was conducted to found the connection between low temperature stress in vivo conditions (ambient-air temperature) and the changes in some physiological and biochemical events (leaf pigments and chlorophyll fluorescence) of mango trees in response to exposure to natural low temperature (cold). To verify this objective, 12 popular commonly mango cultivars (25 years old) which grown in private orchard in Fayoum Governorate, Egypt were selected for this study which carried out during the period from November to March of years; 2012 and 2013. The selected cultivars were: "Alphonso", "Baladi", "Bullock's Heart", "Helmand", "Hindi Besennara", "Mabrouka", "Mestekawy", "Nabeeh", "Oweisi", "Spates", "Taimour" and "Zebda". Based on the obtained results, it can be stated that, chlorophyll (a) concentration in the leaves was significantly differed among the cultivars throughout the whole sampling times, in this respect, "Helmand" one gave the highest one while, and the highest one by sampling times was November one. The concentration of chlorophyll (b) was significant as effected by the effect of cultivars and sampling time recorded the highest value by the cultivar of "Spates" and December sample, respectively. Total chlorophyll concentration in the leaves reached its peak by the cultivar of "Nabeeh" and sampling time of December as compared to others. The both of "Ewais" cultivar and the sample of March showed the highest values of carotenoids concentration in the leaves. The levels of anthocyanin in leaves were significantly differed as affected by the cultivars and sampling times, indicating that the cultivar of "Helmand" and November sample recorded the highest values of anthocyanin in leaves. The greatest reductions in $F v / F m$ ratio were recorded at month of November and indicated that the reductions were in the order of "Alphonso"> "Mabrouka">"Taimour"> others. The effect of sampling time, cultivars and their interaction on $F v / F m$ were significant, but small between some values of $F v / F m$.

The aim of this work was to evaluate the effects of low temperature degrees on leaf pigments and chlorophyll fluorescence in leaves of some cultivars of mango trees under field conditions to choose the best cultivars for cultivation under the conditions of Fayoum Governorate.
\end{abstract}

\section{Introduction}

Mangoes are a popular, nutritional tropical fruit, which are now one of the most important fruits crops in tropical and subtropical areas of the world. They originated in India, were they have been cultivated for more than 4000 years. Beginning in the16th Century, mangoes were gradually distributed from India to other tropical countries in Asia such as the Philippines, Indonesia, China and Thailand. They were also spread to the Americas in the 18th Century, and from western Mexico they were carried to Hawaii in the early 19th century. The first recorded introduction to Florida was at Cape Sable in 1833. Mango was introduced to Egypt in the 18th Century from Ceylon by the Egyptian leader Ahmed Orabi upon his release from internment. Many cultivars grown in Egypt today, such as 'Zibdia' and 'Hindi Be-Sennara' date form this time (Ibrahim and Khalif, 1999). Exposure to low; nonfreezing temperatures induces genetic, morphological, metabolic and physiological changes in plants, which result in the development of cold hardiness and acquisition 
of freezing tolerance (Huner et al., 1993). A mango need an optimum temperature range of 24$26.7^{\circ} \mathrm{C}$ and minimum threshold temperature is $10-12^{\circ} \mathrm{C}$ below this plant shows chilling injury (Allen and Ort, 2001). Mango trees show high susceptibility to low temperature $\left(0-15^{\circ} \mathrm{C}\right)$. Young trees are damaged by low temperature variability among cultivars is apparent after a cold spell, but precise information on this subject is non-existent (Farooq and Azam, 2002). The decline of photosynthetic capacity in low temperature is related to a decrease in the quantum efficiency of PSII (Allen and Ort, 2001). He added that, Photosynthetic apparatus PSII is the primary target of damage under low temperature. Partelli et al. (2009) showed that coffee plants resulted in $30 \%$ reduction in Chlorophyll a, 27\% reduction in Chlorophyll b, 29\% reduction of total Chlorophyll when night temperature decreasing from $20^{\circ} \mathrm{C}$ to $8^{\circ} \mathrm{C}$. Also in $O$. sativa, the total Chlorophyll content was reduced by $50 \%$ due to exposure to low temperature $\left(10^{\circ} \mathrm{C}\right)$ for 2 weeks (Aghaee et al., 2011). In Carplants, $86 \%$ reduction of $\alpha$-carotene, $57 \%$ reduction in $\beta$-carotene, $68 \%$ reduction in $\alpha / \beta$-carotene ratio (Aghaee et al., 2011). The anthocyanin concentrations in both apple and peach shoots increased rapidly during cold acclimation reaching the peak value in early December. The anthocyanin may be accumulated in shoots as a result of leucoanthocyanidin conversion (Leng et al., 2000).Anthocyanin accumulation in green leaves is mainly induced by environmental stresses such as low temperatures (Hao and Arora, 2009).anthocyanins also function as antioxidants, helping maintain toxic reactive oxygen species at low steady-state levels in plants exposed to cold stress (Pennycooke et al., 2005). This is consistent with previous studies indicating that anthocyanin accumulation in green leaves and stems is mainly induced by environmental stresses such as low temperatures and high light. A twofold accumulation of anthocyanins was observed in winter oilseed rape leaves grown in low temperatures for 3 weeks, which was hypothesized to act as a filter that shielded the mesophyll from excessive radiation (Solecka et al., 1999). It has been reported that chlorophyll a, b and carotenoids content was decreased in plants when subjected to cold treatment (Wise and Naylor, 1987). The proportion of closed PSII reaction centers increases as low temperature decreases the rate of photosynthesis. Low temperature also inhibits the rate at which PS II is repaired (Öquist et al., 1993). At temperatures lower than $10^{\circ} \mathrm{C}$, the effects are more pronounced because also membrane-bound chlorophyll may be destroyed by free radicals of oxygen despite the protective action of carotenoids (Smillie et al., 1987). Chlorophyll fluorescence of PSII plays an important role in the response of leaf photosynthesis to environmental stresses (Baker, 1991). The technique measures changes in chlorophyll $a$ fluorescence due to altered photosystem II (PSII) activity,caused directly or indirectly by stress (Percival, 2005). Ratios of the parameters $F v / F m, F o$, and $F v / F o$ provide estimates of various aspects of leaf photosynthetic and photochemical activities (Yamane et al., 2000; Percival and Fraser, 2002). $F v / F m$ measurements from 0.78 to 0.85 are associated with healthy, non-stressed deciduous and evergreen trees (Percival, 2004). The $F v / F m$ ratios for leaves of mango trees were $0.80 \pm 0.03$, for indicating that the photosynthetic processes were functioning normally in autumn (Öquist and Wass, 1988). The $F v / F m$ ratios for mango trees were lower in winter when minimum daily temperatures decreased below $10{ }^{\circ} \mathrm{C}$ compared to early fall when chilling did not occur. The lower $F v / F m$ ratios indicated a reduced photochemical conversion efficiency of PSII (Krause, 1988), which can be an effect of photoinhibition at chilling temperatures (Groom et al., 1991). The use of chlorophyll Fluorescence measurements as a screening method for cold tolerance hasalready been investigated in experiments in which genotypes were compared (Schapendonk et al., 1989 and Dolstra et al., 1994). Chlorophyll fluorescence has been used as a non-intrusive indicator of in vivo photosynthetic reactions and environmental stresses (Gray et al., 1997) of various crop plants. Thus, chlorophyll fluorescence is an indirect measurement of the physiological status of green tissues (Krause and Weis, 1991; Schreiber and Bilger, 1987; Maxwell and Johnson, 2000). Chlorophyll fluorescence has been used to evaluate injuries caused by low temperatures in mango (Smillie et al., 1987), cucumber (Van Kooten et al., 1992) and apples (DeEll et al., 1996 and Mir et al., 1998).Decline in chlorophyll fluorescence in mango is related to the loss of chlorophyll content and chloroplast competence (Smillie et al., 1987). The ratio of $F v / F m$ has an optimal value of 0.83 . When exposed to abiotic and biotic stresses, $F v / F m$ in plants will decrease (Baker, 2008). This parameter is 
therefore frequently used as a stress detector under environmental stress conditions, such as temperature (quist and Huner, 1991).So, CF has been widely used to detect physiological status of plants under different abiotic stress, for example in the presence of nitrogen deficiency, cold and drought (Qin and Zhang, 2005).Yet, research on the physiological basis of cold tolerance of mango has received more attention. Here we attempt to check the changes in leaf pigments and chlorophyll fluorescence that occur following cold exposure.

\section{Materials and Methods}

Atrial was independently conducted during 2012 and 2013, in a private orchard, Fayoum, Egypt, located at $29^{\circ} 22^{\prime} \mathrm{N}$ and $30^{\circ} 47^{\prime} \mathrm{E}$. and in the laboratory of Agricultural Botany Dept., Faculty of Agric., Fayoum University.The experiment assess to check the changes in leaf pigments and chlorophyll fluorescence of some mango cultivars grown under Fayoum Governorate conditions that occur under field conditions.

\section{Climate of experiment site:}

At the site of experiment, temperatures fluctuated during the duration of study and five years before the beginning of the study. In this respect, the mean monthly maximum temperature ( $\left.\mathrm{T}_{\text {Max }}\right)$ ranging from about $17.7^{\circ} \mathrm{C}$ in January 2008 to about $40.2^{\circ} \mathrm{C}$ in August 2010 and the fluctuation in mean monthly minimum temperature $\left(\mathrm{T}_{\text {Min }}\right.$ ) was ranging from about $5.7^{0} \mathrm{C}$ in January $2007 / 2008$ to about $25.2^{\circ} \mathrm{C}$ in August 2012. An extreme minimum temperature of $0.6^{0} \mathrm{C}$ was recorded in January 2008; however, there were large differences between the selected years

(Table 1)*.

\section{Plant materials:}

The plant materials comprised 12 mango cultivars which collected from their natural growing location in the period of November 2012 to march 2013. This is approximately the time at which the cold hardiness may be occurring. Mango trees were about 25 years old, planted in a clay soil at $5 \times 5 \mathrm{~m}$ apart. The cultivars were used in this study including most of the popular cultivars which grown in Fayoum Governorate. The tested cultivars were, "Alphonso", "Baladi", "Bullock's Heart", "Helmand", "Hindi Besennara", "Mabrouka", "Mestekawy", "Nabeeh", "Oweisi", "Spates", "Taimour" and "Zebda". 
(Table 1): The Monthly mean of maximum and minimum temperatures (open airtemperature) during the period from January 2006 to March 2013

\begin{tabular}{|c|c|c|c|c|c|c|c|c|c|}
\hline Month Year & Temp. & 2006 & 2007 & 2008 & 2009 & 2010 & 2011 & 2012 & 2013 \\
\hline \multirow{2}{*}{ January } & Max. & 19.4 & 19.4 & 17.7 & 20.7 & 21.9 & 20.7 & 20.4 & 23.0 \\
\hline & Min. & 6.6 & 5.7 & 5.7 & 6.7 & 7.6 & 8.0 & 7.2 & 10.3 \\
\hline \multirow{2}{*}{ February } & Max. & 22.2 & 21.4 & 20.0 & 22.3 & 24.4 & 22.0 & 22.4 & 24.3 \\
\hline & Min. & 8.4 & 7.8 & 6.5 & 6.4 & 8.2 & 9.4 & 8.2 & 10.4 \\
\hline \multirow{2}{*}{ March } & Max. & 26.3 & 25.0 & 28.6 & 23.2 & 27.5 & 25.6 & 25.4 & 29.0 \\
\hline & Min. & 9.7 & 9.8 & 11.6 & 7.9 & 11.4 & 9.5 & 11.8 & 12.6 \\
\hline \multirow{2}{*}{ April } & Max. & 30.4 & 28.6 & 31.6 & 30.8 & 31.8 & 28.5 & 29.1 & \\
\hline & Min. & 13.3 & 12.5 & 13.7 & 12.5 & 14.3 & 13.7 & 13.6 & \\
\hline \multirow{2}{*}{ May } & Max. & 33.4 & 35.2 & 35.4 & 32.8 & 34.1 & 32.8 & 34.1 & \\
\hline & Min. & 16.9 & 17.7 & 18.2 & 16.7 & 16.7 & 17.4 & 18.3 & \\
\hline \multirow{2}{*}{ June } & Max. & 36.5 & 39.3 & 39.4 & 38.2 & 38.4 & 35.7 & 38.4 & \\
\hline & Min. & 20.0 & 20.7 & 22.0 & 20.4 & 21.4 & 20.6 & 21.8 & \\
\hline \multirow{2}{*}{ July } & Max. & 37.4 & 38.9 & 37.7 & 38.5 & 36.3 & 38.7 & 39.8 & \\
\hline & Min. & 21.3 & 21.8 & 22.1 & 22.7 & 22.4 & 21.5 & 23.6 & \\
\hline \multirow{2}{*}{ August } & Max. & 38.3 & 37.8 & 38.6 & 37.0 & 40.2 & 38.6 & 38.0 & \\
\hline & Min. & 22.1 & 21.7 & 22.2 & 21.8 & 24.5 & 22.9 & 25.2 & \\
\hline \multirow{2}{*}{ September } & Max. & 34.8 & 34.3 & 35.9 & 35.2 & 36.2 & 36.1 & 35.2 & \\
\hline & Min. & 20.3 & 20.5 & 20.0 & 20.7 & 21.9 & 22.1 & 23.4 & \\
\hline \multirow{2}{*}{ October } & Max. & 31.0 & 32.1 & 31.5 & 31.7 & 35.9 & 30.2 & 34.4 & \\
\hline & Min. & 17.2 & 18.3 & 17.2 & 18.1 & 21.3 & 17.7 & 22.2 & \\
\hline \multirow{2}{*}{ November } & Max. & 23.6 & 26.7 & 26.6 & 25.0 & 31.3 & 26.5 & 27.9 & \\
\hline & Min. & 11.1 & 12.8 & 13.1 & 11.7 & 16.5 & 12.6 & 16.4 & \\
\hline \multirow{2}{*}{ December } & Max. & 19.9 & 21.3 & 22.2 & 22.4 & 24.1 & 22.0 & 21.8 & \\
\hline & Min. & 7.5 & 8.2 & 9.1 & 8.9 & 10.3 & 9.7 & 11.0 & \\
\hline
\end{tabular}

* Data applied by Bureau of Meteorology, Agriculture Ademonstration,

Fayoum Governorate, Egypt.

\section{Field trial:}

Thirty-six trees of similar phenotype in the field (size, vigor...etc.) and with management prehistory were selected for this experiment (no further tests were carried out confirm genetic uniformity). All selected trees were allocated at random with each replicate. The trees were derived from seedlings; named "Baladi", while the others they had been grafted onto seedling rootstocks. To obtain a complete picture of mango cold tolerance status under natural condition, measurements must be made at frequent intervals throughout the growth period.

Therefore, samples of ten mature terminal fully expanded leaves (similar development ages) were randomizedly taken from each tree (as a replication) at $30^{\text {th }}$ of each month from November to March. Leaves were collected (between 9 am to $10 \mathrm{am}$ ) from one-year-old shoots of the mango cultivars and used as a plant material. All treatments were applied in a factorial randomized complete block design with three replicates.

\section{Leaf pigments and Carotenoids estimation:}

Chlorophyll (mg g $\left.{ }^{-1} \mathrm{FW}\right)$ were estimated adopting the procedure given by (Arnon, 1949). 100 $\mathrm{mg}$ of leaf sample from different cultivars were collected and homogenized in $25 \mathrm{ml}$ of $80 \%$ acetone using mortar and pestle. The optical density of the acetone extract was measured at 663 , 645 and $452 \mathrm{~nm}$ using visible recording spectrometer (Spectronic 20, Bausch \& lamb). Amount of chlorophyll a, b, total chlorophyll and total Carotenoids are calculated as follows:

Chlorophyll $(\mathrm{A})=[(12.7 \times \mathrm{E} 663)-(2.69 \times \mathrm{E} 645)] \times 0.25 \quad\left(\mathrm{mg} \mathrm{g}^{-1}\right)$ 


$$
\begin{array}{lc}
\text { Chlorophyll }(\mathrm{B})=[(22.4 \times \mathrm{E} 645)-(4.68 \times \mathrm{E} 663)] \times 0.25 & \left(\mathrm{mg} \mathrm{g}^{-1}\right) \\
\text { Total Chlorophyll }=[(8.02 \times \mathrm{E} 663)+(20.2 \times \mathrm{E} 645)] \times 0.25 & \left(\mathrm{mg} \mathrm{g}^{-1}\right) \\
\text { Carotenoids }=[(4.57 \times \mathrm{E} 452)-(0.226 \times \text { Total Chl })] \times 0.25 & \left(\mathrm{mg} \mathrm{g}^{-1}\right)
\end{array}
$$

\section{Determination of Total Anthocyanin:}

Anthocyanin was determined colorimetrically in mango leaves according to Fuleki and Francis (1968) as follows:

$0.1 \mathrm{~g}$ from grounded leaves were macerated with ethanol 95\% and HCL $1.5 \mathrm{~N}(85: 15 \mathrm{v} / \mathrm{v})$ and filtered using a vaccum pump. The absorbency of extracted solution was measured at $535 \mathrm{~nm}$ using spectrophotometer (Spectronic 20 Boasch\& lamb) acidified ethanol was used as the blank absorbance. Anthocyanin content was calculated in absolute quantity with the aid of the extinction coefficient (E1\%1 cm 535 value for anthocyanin 98.2) established for the anthocyanin dissolved in the alcoholic solvent system mentioned. The total Anthocyanin is calculated using the following equation:

Total Anthocyanin mgs per 100 g. $=$ O. D $_{535} \times \mathrm{DW} \times 100 / \mathrm{SW} \times 1 / 98.2$

Where $\quad$ O.D $=$ the optical density of the diluted sample.

$\mathrm{DV}=$ Diluted volume as the volume in mls of the diluted extract prepared for O.D measurements.

$\mathrm{SW}=$ sample weight in grams.

\section{Chlorophyll Fluorescence assay (CF assay):}

At a room temperature, leaf chlorophyll fluorescence (CF) measurements were conducted on the mature fully expanded leaves of each tree using a portable pulse amplitude-modulated fluometer (Handy PEA, Hansatech Instruments Ltd, Kings Lynn, UK). Fluorometer was used to obtain the minimal and maximal $\mathrm{CF}$ (F0 and Fm, respectively), Variable $\mathrm{CF}$ ( $\mathrm{Fv}=\mathrm{Fm}-\mathrm{F} 0$ ), and potential (maximum) quantum yield of PsII $(F v / F m)$ (terminology according to Van Kooten and Snel (1990). This ratio is used as an indicator of plant photosynthetic performance with optimal values around (0.83) (Maxwell and Johnson, 2000). Before measuring CF parameters, Leaves were put in dark-adapted state for 20 min by attaching light exclusion clips to leaf surfaces in situ.Exitation light of $650 \mathrm{~nm}$ (Peak wave length) from a array of three light- emitting diodes is focused on the surface of the leaf to provide a homogenous illumination. Light intensity reaching the leaf was 3000 $\mu$ molm ${ }^{-2} \mathrm{~s}^{-1}$ which was sufficient to generate maximal fluorescence for all the treatments (Mathur et al., 2013). -In all cases, ten leaves (the same developmental stage) were chosen per tree and a total of 30 measurements per treatment were made. Assessment was made at 2 days intervals for cold storage treatment and monthly for the field samples.

\section{Statistical analysis.}

All data were subjected to analysis of variance (ANOVA) using the statistical software package of Genstat (version 11) (VSN International Ltd., Oxford, UK). Means comparison among the different treatments were performed using the least significant differences procedure (LSD) at the $P \leq 0.05$ level as illustrated by Snedecor and Cochran (1980).

\section{Results}

The results of one season were discussed because no significant differences were observed between results of the studied seasons.

\section{Field trial:}

\section{Leaf Pigments:}

\section{A. Chlorophyll A (Chl. A)}

Data in Table (2) show that, the cultivar of "Alphonso had the lowest value of Chl. A at November month followed by "Mestekawy", then "Taimour" ones, in December month, Bullock's 
Heart cultivar recorded the lowest value of Chl. A and the highest value was recorded by spates one. While the highest value was obtained by "Helmand" cultivar. The cultivar of "Hindi Besennara" recorded higher Chl. A value than those recorded by the others in January month and the lowest one was recorded by "Alphonso" cultivar. At the same time it is clear that as sampling dates was lengthened in February month, the Chl. A value was the lowest in "Alphonso" cultivar as compare to the others, while the highest value was recorded by "Nabeeh" cultivar. At the end of experiment; March month, the highest value of Chl. A was recorded by "Hindi Besennara" cultivar and the lowest value by "Spates" one. However, Chl. A concentration was significantly differed among the cultivar throught the whole sampling times since "Alphonso" cultivar gave the lowest value and the "Helmand" gave the higher value. With respect the effect of sampling time, December month sample recorded the highest value of Chl. A and the lowest one was recorded by the sample in March month. Generally, Chl. A concentration was significantly differed among the most of sampling dates.

Table (2): Chlorophyll (A) concentration ( $\mathrm{mg} \mathrm{g}^{-1} \mathrm{FW}$ ) in leaves of mango cultivars at various of sampling dates (November to march) under field conditions.

\begin{tabular}{|l|l|l|l|l|l|l|}
\hline \multirow{2}{*}{ Cultivars } & \multicolumn{6}{|l}{$* *$ Sampling date* (Month) } \\
\cline { 2 - 7 } & Nov. & Dec. & Jan. & Feb. & Mar. & Mean \\
\hline "Alphonso" & 0.80 & 1.68 & 1.19 & 0.95 & 1.22 & $\mathbf{1 . 1 7}$ \\
\hline "Baladi" & 1.71 & 1.75 & 1.53 & 1.43 & 1.23 & $\mathbf{1 . 5 3}$ \\
\hline "Bullock's Heart" & 2.17 & 1.06 & 1.37 & 1.70 & 1.41 & $\mathbf{1 . 5 4}$ \\
\hline "Helmand" & 2.47 & 1.70 & 1.49 & 1.35 & 1.55 & $\mathbf{1 . 7 1}$ \\
\hline "Hindi Besennara" & 1.30 & 1.81 & 1.84 & 1.63 & 1.76 & $\mathbf{1 . 6 7}$ \\
\hline "Mabrouka" & 1.30 & 1.86 & 1.37 & 0.99 & 0.96 & $\mathbf{1 . 3 0}$ \\
\hline "Mestekawy" & 1.14 & 1.76 & 1.82 & 1.22 & 1.23 & $\mathbf{1 . 4 3}$ \\
\hline "Nabeeh" & 2.04 & 1.68 & 1.48 & 1.72 & 1.56 & $\mathbf{1 . 7 0}$ \\
\hline "Oweisi" & 1.67 & 1.65 & 1.68 & 1.00 & 1.16 & $\mathbf{1 . 4 3}$ \\
\hline "Spates" & 1.55 & 2.23 & 1.31 & 1.11 & 0.92 & $\mathbf{1 . 4 2}$ \\
\hline "Taimour" & 1.17 & 2.12 & 1.70 & 1.10 & 1.30 & $\mathbf{1 . 4 8}$ \\
\hline "Zebda" & 1.79 & 1.70 & 1.66 & 1.64 & 1.34 & $\mathbf{1 . 6 3}$ \\
\hline Mean & $\mathbf{1 . 5 9}$ & $\mathbf{1 . 7 5}$ & $\mathbf{1 . 5 4}$ & $\mathbf{1 . 3 2}$ & $\mathbf{1 . 3 0}$ & \\
\hline \multirow{2}{*}{ LSD(5\%) } & $\mathbf{A}$ & $\mathbf{0 . 1 0}$ & & & & \\
\cline { 2 - 7 } & $\mathbf{B}$ & $\mathbf{0 . 1 5}$ & & & & \\
\cline { 2 - 7 } & $\mathbf{A} \mathbf{B}$ & $\mathbf{0 . 3 3}$ & & & & \\
\hline \multirow{2}{*}{ "Hon" } & & & & & \\
\hline
\end{tabular}

$A=$ Sampling date $B=$ Cultivars $\quad A x B=$ Sampling date $\times$ Cultivars

* $\quad$ Each value represents the mean of three replicates

**The sample was taken at the end of each month.

\section{B. Chlorophyll B (Chl. B)}

Based on the results obtained and recorded in Table (3), it can be stated that "Alphonso" cultivar showed lower the value of Chl. B than the other cultivars in November month, while the highest value was recorded by "Spates" cultivar. In decenter month, a noticeable decrease in Chl. B was recorded by "Mabrouka" cultivar comparing with the others. While the higher value was 
recorded by "Mestekawy" cultivar. The concentration of Chl. B in January month, indicate that "Mabrouka" cultivar exhibited the lowest value of Chl. B while, the highest was shown by Spates cultivar. In February month, the concentration of Chl. B in leaves reached it is maximum level by "Zebda" cultivar, while the minimum level was recorded by Both of "Balad"i and "Helmand" cultivars. In March month, a similar decrease was observed by "Helmand" cultivar was high value of Chl. B was recorded by "Spates" cultivar. However, Chl. B concentration was significantly differed among the cultivars during the whole sampling times. Since "Mabrouka" cultivar shown the lowest value and Spates gave the highest value. Regarding, the effect of sampling time, December month sample recorded the highest value of Chl. B and the lowest value was obtained by the sample on February. Generally, Chl. B concentration was significantly differed among the sampling times of the tested cultivars.

Table (3): Chlorophyll (B) concentration ( $\left.\mathrm{mg} \mathrm{g}^{-1} \mathrm{FW}\right)$ in leaves of mango cultivars at various of sampling dates (November to march) under field conditions.

\begin{tabular}{|c|c|c|c|c|c|c|}
\hline \multirow{2}{*}{ Cultivars } & \multicolumn{6}{|c|}{$* *$ Sampling date* (Month) } \\
\hline & Nov. & Dec. & Jan. & Feb. & Mar. & Mean \\
\hline "Alphonso" & 0.65 & 1.16 & 1.25 & 0.67 & 0.46 & 0.84 \\
\hline "Baladi" & 0.99 & 1.26 & 0.85 & 0.38 & 0.55 & 0.81 \\
\hline "Bullock's Heart" & 1.32 & 0.84 & 0.83 & 0.66 & 0.75 & 0.88 \\
\hline "Helmand" & 1.73 & 1.37 & 1.06 & 0.38 & 0.27 & 0.96 \\
\hline "Hindi Besennara" & 0.86 & 1.12 & 0.84 & 0.99 & 1.12 & 0.98 \\
\hline "Mabrouka" & 0.81 & 0.55 & 0.64 & 0.60 & 0.50 & 0.62 \\
\hline "Mestekawy" & 0.72 & 1.56 & 1.18 & 0.89 & 0.94 & 1.06 \\
\hline "Nabeeh" & 1.33 & 1.15 & 1.11 & 0.97 & 1.07 & 1.13 \\
\hline "Oweisi" & 1.12 & 0.98 & 0.77 & 0.58 & 0.31 & 0.75 \\
\hline "Spates" & 1.48 & 1.34 & 1.46 & 0.91 & 1.29 & 1.29 \\
\hline "Taimour" & 0.76 & 1.22 & 1.03 & 0.68 & 0.56 & 0.85 \\
\hline "Zebda" & 1.22 & 1.12 & 1.05 & 1.00 & 0.97 & 1.07 \\
\hline Mean & 1.08 & 1.14 & 1.01 & 0.72 & 0.73 & \\
\hline \multirow{3}{*}{$\operatorname{LSD}_{(5 \%)}$} & $\mathbf{A}$ & \multicolumn{5}{|l|}{0.10} \\
\hline & B & \multicolumn{5}{|l|}{0.16} \\
\hline & $\mathbf{A} \times \mathbf{B}$ & \multicolumn{5}{|l|}{0.36} \\
\hline
\end{tabular}

$A=$ Sampling date $B=$ Cultivars $\quad A x B=$ Sampling date $x$ Cultivars

$* \quad$ Each value represents the mean of three replicates
$* *$ The sample was taken at the end of each month.

C. Total Chlorophyll (T.Chl.)

The results inTable (4) show that, the cultivar of "Alphonso" had the lowest value of T. Chl. At November month followed by "Mestekawy" then "Taimour" ones, while the greater value was obtained by "Helmand" cultivar. In December, "Bullock's Heart" recorded the lowest value of T.Chl. The cultivar of "spates" recorded the highest value of T.Chl. than those recorded by the others. In January, the lowest value of T.Chl. was given by "Mabrouka" cultivar and the highest value was shown by "Mestekawy" one. 
When the sampling date was lengthened, the T.Chl. Value was the lowest by "Oweisi" cultivar and the highest value was recorded by "Nabeeh" one in February month. At the end of experiment, at March month, lowest concentration of T.Chl. was given by "Oweisi" cultivar and the highest one was recorded by "Hindi Besennara" cultivar. However, T.Chl. Concentration was significantly differed among the cultivars throughout the all sampling times, since "Nabeeh" cultivar gave the highest value and" Mabrouka" cultivar gave the lowest one. Regarding, the effect of sampling times, the December month sample recorded the highest value of T.Chl. and the lowest one was recorded by the sample in March month. In addition, T.Chl. Concentration was significantly differed among the most of sampling dates. Generally, of T.Chl. was significantly differed among the sampling times of the tested cultivars.

Table (4): Total Chlorophyll concentration ( $\left.\mathrm{mg} \mathrm{g}^{-1} \mathrm{FW}\right)$ in leaves of mango cultivars at various of sampling dates (November to march) under field conditions.

\begin{tabular}{|l|l|l|l|l|l|l|}
\hline \multirow{2}{*}{ Cultivars } & \multicolumn{6}{|l}{$* *$ Sampling date* (Month) } \\
\cline { 2 - 7 } & Nov. & Dec. & Jan. & Feb. & Mar. & Mean \\
\hline "Alphonso" & 5.89 & 11.55 & 9.95 & 6.57 & 6.80 & $\mathbf{8 . 1 5}$ \\
\hline "Baladi" & 10.97 & 12.23 & 9.62 & 7.34 & 7.19 & $\mathbf{9 . 4 7}$ \\
\hline "Bullock's Heart" & 14.16 & 7.72 & 8.93 & 9.55 & 8.74 & $\mathbf{9 . 8 2}$ \\
\hline "Helmand" & 17.05 & 12.46 & 10.34 & 6.99 & 7.34 & $\mathbf{1 0 . 8 3}$ \\
\hline "Hindi Besennara" & 8.77 & 11.87 & 10.86 & 10.62 & 11.67 & $\mathbf{1 0 . 7 5}$ \\
\hline "Mabrouka" & 8.54 & 9.73 & 8.13 & 6.44 & 5.93 & $\mathbf{7 . 7 5}$ \\
\hline "Mestekawy" & 7.54 & 13.51 & 12.19 & 8.55 & 8.81 & $\mathbf{1 0 . 1 2}$ \\
\hline "Nabeeh" & 13.71 & 11.48 & 10.54 & 10.93 & 10.66 & $\mathbf{1 1 . 4 6}$ \\
\hline "Oweisi" & 11.29 & 10.67 & 9.93 & 6.40 & 5.92 & $\mathbf{8 . 8 4}$ \\
\hline "Spates" & 12.32 & 14.46 & 11.27 & 8.22 & 8.96 & $\mathbf{1 1 . 0 4}$ \\
\hline "Taimour" & 7.85 & 13.53 & 11.07 & 7.24 & 7.51 & $\mathbf{9 . 4 4}$ \\
\hline "Zebda" & 12.18 & 11.44 & 10.99 & 10.71 & 9.37 & $\mathbf{1 0 . 9 4}$ \\
\hline Mean & $\mathbf{1 0 . 8 6}$ & $\mathbf{1 1 . 7 2}$ & $\mathbf{1 0 . 3 2}$ & $\mathbf{8 . 3 0}$ & $\mathbf{8 . 2 4}$ & \\
\hline \multirow{2}{*}{ LSD(5\%) } & $\mathbf{A}$ & $\mathbf{0 . 4 5}$ & & & & \\
\cline { 2 - 7 } & $\mathbf{B}$ & $\mathbf{0 . 7 0}$ & & & & \\
\cline { 2 - 7 } & $\mathbf{A} \mathbf{x}$ B & $\mathbf{1 . 5 6}$ & & & & \\
\hline
\end{tabular}

$A=$ Sampling date $\quad B=$ Cultivars $\quad \mathbf{A x B}=$ Sampling date $\times$ Cultivars

* $\quad$ Each value represents the mean of three replicates

**The sample was taken at the end of each month.

D. Carotenoids:

The changes in carotenoids concentration in leaves of Mango cultivars during the sampling dates from November to March are shown in Table (5). Results obtained show that "Alphonso" and "Hindi Besennara" cultivars gave the lowest value of carotenoids than the others, while the highest value was recorded by "Spates" cultivar in November month. The highest value of carotenoids in December month was obtained by "Zebda" cultivar, while the lowest value was recorded by 
"Mabrouka" cultivar one. In January month, both of "Spates" and "Taimour" cultivars gave the lowest values of carotenoids and the highest value was recorded by "Alphonso" cultivar. In February month, the concentration of carotenoids in leaves reached its maximum level by "Oweisi" cultivar, while the minimum level was recorded by "Alphonso" cultivar. A similar decrease in value of carotenoids was observed by the cultivar of "Bullock's Heart", while the highest value was recorded by "Oweisi" cultivar one. However, it's obvious that carotenoids concentration was significantly differed among the cultivars during the whole sampling dates. Since "Mabrouk"a cultivar showed the lowest value and "Oweisi" cultivar gave the highest value. With respect to, the effect of sampling time, March sample recorded the highest of carotenoids and the lowest one was obtained by the sample of February month. Generally, the values of carotenoids were significantly differed among the sampling times of the tested cultivars.

Table (5): Carotenoids concentration ( $\mathrm{mg} \mathrm{g}^{-1} \mathrm{FW}$ ) in leaves of mango cultivars at various of sampling dates (November to march) under field conditions.

\begin{tabular}{|l|l|l|l|l|l|l|}
\hline \multirow{2}{*}{ Cultivars } & \multicolumn{6}{|l}{$* *$ Sampling date* (Month) } \\
\cline { 2 - 7 } & Nov. & Dec. & Jan. & Feb. & Mar. & Mean \\
\hline "Alphonso" & 0.26 & 0.45 & 0.58 & 0.23 & 0.72 & $\mathbf{0 . 4 5}$ \\
\hline "Baladi" & 0.33 & 0.39 & 0.54 & 0.47 & 0.65 & $\mathbf{0 . 4 8}$ \\
\hline "Bullock's Heart" & 0.32 & 0.38 & 0.38 & 0.44 & 0.40 & $\mathbf{0 . 3 8}$ \\
\hline "Helmand" & 0.37 & 0.44 & 0.41 & 0.37 & 0.59 & $\mathbf{0 . 4 4}$ \\
\hline "Hindi Besennara" & 0.26 & 0.47 & 0.44 & 0.50 & 0.48 & $\mathbf{0 . 4 3}$ \\
\hline "Mabrouka" & 0.29 & 0.20 & 0.38 & 0.25 & 0.53 & $\mathbf{0 . 3 3}$ \\
\hline "Mestekawy" & 0.27 & 0.49 & 0.40 & 0.47 & 0.76 & $\mathbf{0 . 4 8}$ \\
\hline "Nabeeh" & 0.40 & 0.49 & 0.46 & 0.34 & 0.49 & $\mathbf{0 . 4 4}$ \\
\hline "Oweisi" & 0.37 & 0.46 & 0.49 & 0.72 & 0.74 & $\mathbf{0 . 5 6}$ \\
\hline "Spates" & 0.56 & 0.33 & 0.34 & 0.27 & 0.54 & $\mathbf{0 . 4 1}$ \\
\hline "Taimour" & 0.49 & 0.49 & 0.34 & 0.43 & 0.57 & $\mathbf{0 . 4 6}$ \\
\hline "Zebda" & 0.38 & 0.50 & 0.43 & 0.40 & 0.61 & $\mathbf{0 . 4 6}$ \\
\hline \multirow{2}{*}{ Mean } & $\mathbf{0 . 3 6}$ & $\mathbf{0 . 4 3}$ & $\mathbf{0 . 4 3}$ & $\mathbf{0 . 4 1}$ & $\mathbf{0 . 5 9}$ & \\
\hline \multirow{2}{*}{ LSD(5\%) } & $\mathbf{A}$ & $\mathbf{0 . 0 4}$ & & & & \\
\cline { 2 - 7 } & $\mathbf{B}$ & $\mathbf{0 . 0 6}$ & $\mathbf{0 . 1 2}$ & & & \\
\cline { 2 - 7 } & $\mathbf{A} \mathbf{B}$ & $\mathbf{0}$ & & & \\
\hline
\end{tabular}

\section{$A=$ Sampling date $\quad B=$ Cultivars $\quad \mathbf{A x B}=$ Sampling date $x$ Cultivars}

\section{* $\quad$ Each value represents the mean of three replicates}

**The sample was taken at the end of each month.

\section{E. Anthocyanin:}

The changes in anthocyanin concentration in leaves of Mango cultivars were evaluated in Table (6). The results showed that the anthocyanin concentration reached its peak level by "Bullock's Heart" cultivar but the lowest level of anthocyanin during November was recorded by Spates cultivar. The maximum level of anthocyanin in December was exhibited by "Helmand" cultivar and the lowest by "Spates" cultivar. In January, the cultivars of "Alphonso", "Mabrouka" 
and "Oweisi" showed the lowest values of anthocyanin, while the greater value recorded by "Mestekawy" cultivar. However, the concentration anthocyanin reached its minimum level by "Spates" cultivar and the maximum level by "Mestekawy" cultivar one. But in March, the cultivar "Helmand" recorded the highest value of anthocyanin in leaves of Mango with the lowest level in leaves of "Oweisi" one. However, anthocyanin concentration was significantly differed among the cultivars during the whole sampling dates. In this respect, "Alphonso" cultivar gave the lowest value and the highest value was shown by "Helmand" cultivar. Regarding, the effect of sampling time, November month, sample recorded the greater value of anthocyanin and the lowest one was given by the sample in February month. Generally, the value of anthocyanin was significantly differed among the sampling times of the tested cultivars.

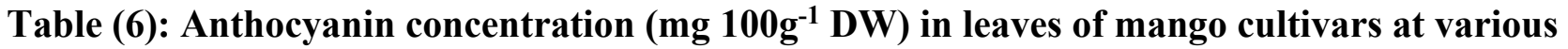
of sampling dates (November to march) under field conditions.

\begin{tabular}{|l|l|l|l|l|l|l|}
\hline \multirow{2}{*}{ Cultivars } & \multicolumn{6}{|l}{$* *$ Sampling date* (Month) } \\
\cline { 2 - 7 } & Nov. & Dec. & Jan. & Feb. & Mar. & Mean \\
\hline "Alphonso" & 48.54 & 46.84 & 39.38 & 38.70 & 43.79 & $\mathbf{4 3 . 4 5}$ \\
\hline "Baladi" & 68.23 & 61.10 & 51.93 & 45.82 & 52.61 & $\mathbf{5 5 . 9 4}$ \\
\hline "Bullock's Heart" & 108.62 & 53.97 & 56.01 & 45.82 & 51.60 & $\mathbf{6 3 . 2 0}$ \\
\hline "Helmand" & 84.18 & 70.26 & 50.92 & 57.71 & 65.85 & $\mathbf{6 5 . 7 8}$ \\
\hline "Hindi Besennara" & 56.01 & 49.90 & 42.77 & 40.73 & 47.52 & $\mathbf{4 7 . 3 9}$ \\
\hline "Mabrouka" & 55.67 & 52.61 & 39.38 & 46.84 & 51.93 & $\mathbf{4 9 . 2 9}$ \\
\hline "Mestekawy" & 65.17 & 41.75 & 60.08 & 61.10 & 53.97 & $\mathbf{5 6 . 4 2}$ \\
\hline "Nabeeh" & 60.08 & 59.06 & 40.73 & 47.52 & 61.10 & $\mathbf{5 3 . 7 0}$ \\
\hline "Oweisi" & 65.85 & 51.93 & 39.38 & 38.7 & 32.25 & $\mathbf{4 5 . 6 2}$ \\
\hline "Spates" & 47.52 & 41.41 & 51.60 & 37.68 & 46.84 & $\mathbf{4 5 . 0 1}$ \\
\hline "Taimour" & 63.14 & 51.93 & 53.97 & 50.58 & 45.82 & $\mathbf{5 3 . 0 9}$ \\
\hline "Zebda" & 88.26 & 63.14 & 59.06 & 46.84 & 51.93 & $\mathbf{6 1 . 8 5}$ \\
\hline Mean & $\mathbf{6 7 . 6 1}$ & $\mathbf{5 3 . 6 6}$ & $\mathbf{4 8 . 7 7}$ & $\mathbf{4 6 . 5}$ & $\mathbf{5 0 . 4 4}$ & \\
\hline \multirow{2}{*}{ LSD(5\%) } & $\mathbf{A}$ & $\mathbf{1 . 8 0}$ & & & & \\
\cline { 2 - 7 } & $\mathbf{B}$ & $\mathbf{2 . 7 9}$ & & & & \\
\cline { 2 - 7 } & $\mathbf{A} \mathbf{x}$ B & $\mathbf{6 . 2 3}$ & & & & \\
\hline
\end{tabular}

\section{$A=$ Sampling date $\quad B=$ Cultivars $\quad \mathbf{A x B}=$ Sampling date $x$ Cultivars}

* $\quad$ Each value represents the mean of three replicates

**The sample was taken at the end of each month.

\section{F. Evaluation of changes in Chlorophyll Fluorescence (CF):}

Chlorophyll fluorescence (CF) was investigated for evaluating its application in monitoring cold tolerance of Mango cultivars. Results in Table (7) showed that the greatest reduction in were recorded at month of November, indicating maximal damage to the leaf photosynthetic system. Reduction in $F v / F m$ at month of November indicated species cold tolerance in the order "Alphonso"> "Mabrouka">"Taimour"> others. From November onward, a steady recovery of the 
leaf photosynthetic system was recorded in all species in December month. In January, the lowest value of $F v / F m$ was obtained by "Hindi Besennara' followed by "Mabrouk"a cultivar, while the higher value of $F v / F m$ could be obtained by "Mestekawy" cultivar. However, the value of $F v / F m$ ranging from $0.66-0.82 . F v / F m$ values of $\mathrm{CF}$ emitted from cultivars in February indicate that the values were very similar to those obtained by cultivars in each of November, December and January months. In this respect, it could be seen that, "Mabrouka" cultivar recorded the lowest value of $F v / F m(0.58)$ as compared to the others, while the highest value $F v / F m$ was recorded by the cultivar of "Mestekawy". The differences in $F v / F m$ among cultivars showed a similar trend to those in the previous months, although the order was reverse, were cultivar of "Bullock's Heart" recorded the lowest value of $F v / F m$ against the others, while the highest value obtained by "Taimour" cultivar. ANOVA analysis revealed that the effect of sampling time, cultivar and interaction of cultivars and sampling time were significant at $P=0.05$, but small between the $F v / F m$. Generally, the $F v / F m$ was affected by air ambient temperature under field conditions and may vary with cultivars and sampling times. Thus, the most notably among cultivars were differences in $F v / F m$ which may partly explain the differences cold tolerance between the tested cultivars. Generally, the value of $\mathrm{Fv} / \mathrm{Fm}$ was significantly differed among the sampling times of the tested cultivars.

Table (7): Changes in $\mathrm{Fv} / \mathrm{Fm}$ values of chlorophyll fluorescence in leaves of mango cultivars at various of sampling dates (November to march) under field conditions.

\begin{tabular}{|c|c|c|c|c|c|c|}
\hline \multirow{2}{*}{ Cultivars } & \multicolumn{6}{|c|}{$* *$ Sampling date* (Month) } \\
\hline & Nov. & Dec. & Jan. & Feb. & Mar. & Mean \\
\hline "Alphonso" & 0.52 & 0.77 & 0.79 & 0.78 & 0.79 & 0.65 \\
\hline "Baladi" & 0.78 & 0.80 & 0.81 & 0.81 & 0.79 & 0.79 \\
\hline "Bullock's Heart" & 0.77 & 0.81 & 0.77 & 0.80 & 0.70 & 0.79 \\
\hline "Helmand" & 0.78 & 0.81 & 0.81 & 0.82 & 0.77 & 0.80 \\
\hline "Hindi Besennara" & 0.78 & 0.82 & 0.66 & 0.82 & 0.71 & 0.80 \\
\hline "Mabrouka" & 0.68 & 0.74 & 0.69 & 0.58 & 0.74 & 0.71 \\
\hline "Mestekawy" & 0.79 & 0.83 & 0.82 & 0.83 & 0.77 & 0.81 \\
\hline "Nabeeh" & 0.78 & 0.80 & 0.76 & 0.79 & 0.80 & 0.79 \\
\hline "Oweisi" & 0.80 & 0.78 & 0.79 & 0.62 & 0.80 & 0.79 \\
\hline "Spates" & 0.80 & 0.82 & 0.74 & 0.71 & 0.80 & 0.81 \\
\hline "Taimour" & 0.70 & 0.81 & 0.76 & 0.77 & 0.82 & 0.76 \\
\hline "Zebda" & 0.80 & 0.81 & 0.70 & 0.81 & 0.75 & 0.81 \\
\hline Mean & 0.75 & 0.80 & 0.76 & 0.76 & 0.77 & \\
\hline \multirow{3}{*}{$\operatorname{LSD}_{(5 \%)}$} & $\mathbf{A}$ & \multicolumn{5}{|l|}{0.01} \\
\hline & B & \multicolumn{5}{|l|}{0.03} \\
\hline & $A \times B$ & \multicolumn{5}{|l|}{0.05} \\
\hline
\end{tabular}

$A=$ Sampling date $\quad B=$ Cultivars $\quad A x B=$ Sampling date $x$ Cultivars 


\section{Discussion}

Chilling temperatures (lower than $15^{\circ} \mathrm{C}$ ) lead to numerous physiological disturbances in the cells of chilling-sensitive plant and result in chilling injury and death of tropical and subtropical (Lukatkin et al., 2012). Obviously, the problem of plant resistance to chilling temperature, which often occurs in spring and autumn in many countries, is important for practical plant breeding. A change in the Egyptian climate has already been observed during the last decades, and this is expected to continue throughout this century. This change in climate affects the behavior of fruit trees and their productivity. In 2008, Egypt was exposed to a wave of frost that caused severe damage to mango trees; Hence, there is a need to know which cultivars are resistant to winter cold (Ismail, 2014).

As a result of this sensitivity, low temperature produce a range of physiological and metabolic disorders that lead to serious losses. The various dysfunctions that arise under low temperature conditions result in various physical and metabolic changes that are easily scored and which can therefore be used to assess the degree of chilling injury. Thus, the aim of this trail is to study the change in leaf pigments and chlorophyll fluorescence as indicators for determine index of some mango cultivars and to know which of them are resistant to chilling temperatures.

\section{Leaf pigments.}

In fresh leaf samples, the concentration of leaf pigments; chlorophyll $a, b$, total, carotenoids and anthocyanin increased in some cultivars than the others specially. Under field conditions, the cultivars of "Helmand", "Spates", "Nabeeh" and "Ewais" recorded the highest values of chlorophyll $\mathrm{a}$ and anthocyanin, chlorophyll b, T. chlorophyll and carotenoids, orderly (Tables 2, 3, 4, 5 and 6). While, the lowest values of leaf pigments were exhibited by the cultivars of "Alphonso" (Chl.a and anthocyanin) and "Mabrouka" (Chl.b, T.chl. and carotenoids). Based on the previously obtained results the decrease in chlorophyll concentrations in some cultivars may be attributed to increase activity of chlorophyll-degrading enzyme chlorophyllase under low temperature stress conditions and may by inhibition of their biosynthesis (Reddy and Vora, 1986). At low temperatures, the low chlorophyll content can be seen as an indication for a deficiency of photosynthetic capacity of the leaves (Schapendonk et al., 1989 and Kingston-Smith and Foyer, 2000). Partelli et al. (2009) showed that coffee plants resulted in $30 \%$ reduction in chlorophyll a, $27 \%$ reduction in chlorophyll b, $29 \%$ reduction of total chlorophyll when night temperature decreasing from $20^{\circ} \mathrm{C}$ to $8^{\circ} \mathrm{C}$ and by $50 \%$ reduction due to exposure to low temperature $\left(10^{\circ} \mathrm{C}\right)$ for 2 weeks (Aghaee et al., 2011). Decrease of photosynthesis at chilling temperatures may be a consequence of photo-oxidative damage to the photosystems in the membranes of chloroplasts which is manifested by increased degradation of chlorophyll and carotenes (Kingston-Smith and Foyer, 2000). Carotenoids and consequently, chlorophyll a and b deplete after a lag time of 3 to 6 hours of exposure to low temperatures (Wise and Naylor, 1987).

The anthocyanin accumulate in leaves and stems in response to low temperatures. It has been reported that cold stress induces transcriptomic modification that increase flavonoid biosynthesis, including reactions involved in anthocyanin biosynthesis and metabolic pathways that supply it. It is conceivable that enhanced cold tolerance of plants may be partly be associated with increased activity of antioxidant system and photo-oxidation prevention from induced anthocyanins which accumulate in leaves under low temperatures (Hao and Arora, 2009).

In fact, the low temperature in autumn induced an increase in the activity of phenylalanine ammonia-layse in persimmon shoots. The activity of this enzyme reached its maximum level during the period from autumn to winter (Leng et al., 1995). These results are in agreement with the findings of researchers; Luo and Wang (1994) and Pennycooke et al. (2005).

\section{Chlorophyll fluorescence (CF).}

The relationship between low temperature stress and the responses of different mango cultivars which tested in this study was monitored on changes in its fluorescence yields as expressed in $F v / F m$ through the application of a non-destructive technique-chlorophyll fluorescence. $F v / F m$ values that were higher than 0.6 were classified as chilling tolerant and values starting from 
0.5 and below as chilling sensitive (Lao et al., 2010). Hence, under field conditions, the all tested cultivars of mango are chilling tolerant with the highest value of $F v / F m b y$ the cultivars of "Mestekawy", "Spates" and "Zebda" and the lowest ones by the cultivar of "Alphonso" (Table 7). The genotype or the parental lines mango cultivars transfers traits that will be intensified upon exposure to low temperature stress, such as better ROS scavenging capacity or higher unsaturation of fatty acids (Lyons et al., 1964). Decline in $F v / F m$ values were attributed to a rise in stomatal limitation of net $\mathrm{CO} 2$ assimilation rate and a decrease Rubisco activity (Allen et al., 2000). However, leaf detachment acts by hastering the decrease of chlorophyll as reported by Potvin (1985) while, studying its effects on bean, maize and cucumber. In this respect, $F v / F$ $m$ measurements from 0.78-0.85 are associated with healthy, non-stressed delicious and evergreen trees (Percival, 2004) or near 0.80 (Mohammed et al., 1995). The $F v / F m$ ratios for leaves of mango trees were $0.80 \pm 0.03$, for indicating that photosynthetic processes were functioning normally in autumn. The $F v / F m$ ratios for mango tress were lower in winter when minimum daily temperatures decreased below $10^{\circ} \mathrm{C}$ compared to early splitting and degradation of the protein of PSII (Krause and Weis, 1991). The decline of CF under low-temperature stress was probably due to chlorophyll degradation and also to the degree of chloroplast membrane injury (Bron et al., 2004). Thus, the chlorophyll fluorescence provides a tool to classify the impact of low temperature on basic physiological processes. As such the method may improve the basis for genetic analysis of yield reduction due to low temperature treatments fall when chilling did not occur (Öquist and Wass, 1988). The lower $F v / F m$ ratios indicated a reduced photochemical conversion efficiency of PSII (Krause, 1988), which can be an effect of photoinhibition at chilling temperatures (Groom et al., 1991). The ratio of $F v / F m$ has an optimal value of 0.83 when exposed to abiotic and biotic stresses; Fv/Fmin plants will decrease (Baker, 2008). This parameter is therefore, frequently used as stress detector under environmental stress conditions, such as low temperature (Öquist and Huner, 1991). Low-temperature induced inhibition also involves reduced electron transfer via PSII due to down-regulation of water. The decrease in $F v / F m$ was associated with decreases in both $F 0$ and $F m$. these parameters represent the fluorescence yield when all reaction centers of PSII are open and closed, respectively (Van Kooten and Snel, 1990). Decreases in Fmindicate an increase in heat formation in both the reaction center and antenna of PSII (Schreiber et al., 1998), whereas changes in $\mathrm{FO}$ are due to structural alterations in the thylakoid membranes (Kitao et al., 2000).

\section{References}

[1] Aghaee, A., Moradi, F., Zare-maivan, H., Zarinkamar, F., Irandoost, H. P, and Sharifi, P. (2011). Physiological responses of two rice (Oryza sativa L.) genotypes to chilling stress atseedling stage. African Journal of Biotechnology, 10(39):7617-7621.

[2] Allen, D. J. and Ort, D. R. (2001). Impacts of chilling temperatures on photosynthesis in warm climate plants. Trends in Plant Science, 6:36-42.

[3] Allen, D.J.; Ramer, K.; Giller, Y.E.; Gussakovsky, E.E.; Shahak, Y. and Ort. D. (2000). An overnight chill induces a delayed inhibition of photosynthesis at midday in mango (Mangifera indica L.). J. Exp. Bot., 51(352): 1893-1902.

[4] Arnon, D.I. (1949). Copper enzymes in isolated chloroplast. Polyphenol-oxidase in Beta Vulgaris L. plant Physiol., 24:1-5.

[5] Baker, N.R. (1991). A possible role for photosystem II in environmental perturbations of photosynthesis. Plant Physiol., 81:563-570.

[6] Baker, N.R. (2008). Chlorophyll fluorescence: A probe of photosynthesis in vivo. Ann. Rev. Plant Bio., 59: 89-113.

[7] Bron, I.U.; Ribeiro, R.V.; Azzolini, M.; Jacomino, P.A. and Machado, C.E. (2004). Chlorophyll fluorescence as a tool to evaluate the ripening of 'Golden' papaya fruit.Post.Biol. and Techn. 33: 163-173. 
[8] DeEll, J.R.; Prange, R.K. and Murr, D.P. (1996). Chlorophyll fluorescence of delicious apples at harvest as a potential predictor of superficial scald development during storage. Post. Biol. Tech., 9: 1-6.

[9] Dolstra, O.; Haalstra, S.R.; Van der Putten, P.E.L. and Schapendonk, AHCM.(1994). Genetic variation for resistance to low-temperature photoinhibition of photosynthesis in maize. Euphytica, 80: 85-93.

[10] Farooq, S. and Azam, F. (2002). The Co-existence of salt and drought tolerance in Triticaceae. Hereditas, 135:205-210.

[11] Fuleki, T, and Francis, F.J. (1968). Quantitative methods for anthocyanins: I. Extraction and determination of total anthocyanin in cranberries. J. Food Sci., 3: 72-77.

[12] Ghassemi-Golezani, K., Khomari, S., Valizadeh, M. and Alyari, H. (2008).Changes in chlorophyll content and fluorescence of leaves of winter rapeseed affected by seedling vigor and cold acclimation duration. J. Food Agric. Environ., 6:196-199.

[13] Gray, G. R., Savitch, L. V., Ivanov, A. G. and Huner, N.P.A. (1996). PhotosystemII excitation pressure and development of resistance tophotoinhibition. II. Adjustment of photosynthetic capacity inwinter wheat and winter rye. Plant Physiol., 110:61-71.

[14] Groom, Q.J.; Baker, N.R. and Long, S.P. (1991). Photoinhibition of holly (Ilex aquifolium) in the field during the winter. Plant Physiol., 83: 585-590.

[15] Hao, W. and Arora, R. (2009). Freezing Tolerance and Cold Acclimation in Guava (Psidiumguajava L.). Hortscience, 44(5):1258-1266.

[16] Huner, N. P. A., Öquist, G., Hurry, V. M., Krol, M., Falk, S. and Griffith, M. (1993). Photosynthesis, Photoinhibition and low temperature acclimationin cold tolerant plants. Photosynth Res., 37:19-39.

[17] Ibrahim, A.M. and Khalif, M.N. (1999). Mangoes: Cultivation, Caring and Production. Eds Ibrahim, A.M., (First edition): ISSN: 977-03-0452-4.

[18] Ismail, O.M. (2014). Use of electrical conductivity as a tool for determining damage index of some mango cultivars. Inter. J. Plant \& Soil Sci., 3(5): 448-456.

[19] Kingston-Smith, A.H. and Foyer, C.H. (2000). Bundle-sheath proteins are more sensitive to oxidative damage than those of the mesophyll in maize leaves exposed to paraquat or low temperatures. J. Exper. Bot., 51(342): 123-130.

[20] Kitao, M.; Lei, T.T.; Koike, T.; Tobita, H.; Maruyama, Y.; Matsumoto, Y. and Ang, L. (2000). Temperature response and photoinhibition investigated by chlorophyll fluorescence measurements for four distinct species of dipterocarp trees. Plant Physiol., 109: 284-290.

[21] Krause, G.G. (1988). Photoinhibition of photosynthesis.An evaluation of damaging and protective mechanisms. Plant Physiol., 74: 566-574.

[22] Krause, G.H and Weis, E. (1991). Chlorophyll fluorescence and photosynthesis. The basics. Ann. Rev. Plant Physiol., 42: 313-349.

[23] Lao, D.L.; Shiesh, C.C. and Lin, L.H. (2010). Determination of chilling sensitivity of mango (MangiferaindicaL.) leaves using chlorophyll fluorescence. Hort. NCHU, 35(4): 2332.

[24] Leng, P., Itamura, H., Yamamura, H., (1995). Changes of phenylalanine ammonialyase activity in twig tissues of two Diospyros species during cold acclimation. (in Japanese, with English abstract). Environ. Control in Biol., 33:43-48.

[25] Leng, P., Itamura, H., Yamamura, H. and Deng X. M. (2000). Anthocyanin accumulation in apple and peach shootsduring cold acclimation. Scientia Horticulturae, 83:43-50. 
[26] Lukatkin, A. S., Brazaitytè, A., Bobinas, C. Duchovskis, P. (2012). Chilling injury in chilling-sensitive plants: a review, Žemdirbystè-Agriculture, 99(2):111-124.

[27] Luo, G. H. and Wang, A. G. (1994). The scavenging effect of plant polyphenolics on superoxide radicals.(in Chinese, with English abstract). J. Tropical and Subtropical Bot., 2:9599.

[28] Lyons, J.M.; Wheaton, T.A. and Pratt, H.K. (1964).Relationship between the physical nature of mitochondrial membranes and chilling sensitivity in plants. Plant Physiol., 39: 262268.

[29] Mathur, S.; Mehta, P. and Jajoo, A. (2013). Effects of dual stress (high salt and high temperature) on the photochemical efficiency of wheat leaves (Triticum aestivum L.). Physiol. Mol. Biol. Plants, 19(2): 179-188.

[30] Maxwell, K. and Johnson, G. N. (2000). Chlorophyll fluorescence- a practical guide. J. Exp. Bot., 51:659-668.

[31] Mir, N.A.; Perez, R. and Beaudry, R.M. (1998).Chlorophyll fluorescence and whole fruit senescence in 'golden delicious' apple. Acta Hortic., 464: 121-126.

[32] Mohammed, G.H.; Binder, B.D. and Gillies, S.L. (1995). Chlorophyll fluorescence: a review of its practical forestry applications and instrumentation. Scand. J. For. Res., 10: 383410.

[33] Öquist, G. and Huner, N.P.A. (1991). Effects of cold acclimation on the susceptibility of photosynthesis to photoinhibition in Scots pine and in winter and spring cereals: a fluorescence analysis. Funct. Ecol., 5: 91-100.

[34] Öquist, G. and Wass.R. (1988). A portable microprocessor operated instrument for measuring chlorophyll fluorescence kinetics in stress physiology. Plant Physiol., 73: 211-217.

[35] Öquist, G., Hurry, V. M. and Huner, N. P. A. (1993). Low-temperature effectson photosynthesis and correlation with freezing tolerance inspring andwinter cultivars of wheat and rye. Plant Physiol., 101:245-250.

[36] Partelli, F. L., Vieira, H. D., Viana, A. P. Batista-Santos, P., Rodrigues, A. P., Leitão, A. E. and Ramalho, J. C. (2009). Low temperature impact on photosynthetic parameters of coffee genotypes.Pesquisa Agropecuária Brasileira, 44:1404-1415.

[37] Pellett, H.; Gearhart, M. and Dirr, M. (1981).Cold hardiness capability of woody ornamental plant taxa. J. Ame. Soc. Hort. Sci., 106: 239-243.

[38] Pennycooke, J. C., Cox, S. and Stushnoff, C. (2005). Relationship of cold acclimation, total phenoliccontent and antioxidant capacity with chilling tolerance in petunia (Petunia $\times$ hybrida). Environ. Exp. Bot., 53:225-232.

[39] Percival, G.C. (2004). Evaluation of physiological tests as predictors of young tree establishment and growth. J. Arboric., 30(2): 80-92.

[40] Percival, G.C. (2005). The use of chlorophyll fluorescence to identify chemical and environmental stress in leaf tissue of three oak (quercus) species. J. Arboric., 31(5): 215-227.

[41] Percival, G.C. and Fraser, G.A. (2002).The influence of powdery mildew infection on photosynthesis, chlorophyll fluorescence, leaf chlorophyll and carotenoid content of three woody species.Arboric. J., 26(4): 333-347.

[42] Potvin, C. (1985). Effect of leaf detachment on chlorophyll fluorescence during chilling experiments. Plant Physiol., 78: 883-886. 
[43] Qin, Z.H. and Zhang, M.H. (2005). Detection of rice sheath blight for in-season disease management using multispectral remote sensing. Int. J. Appl. Earth Observation Geoinf., 7: $115-114$.

[44] Reddy, M.P and Vora, A.B. (1986). Changes in pigment composition, hill reaction activity and saccharide metabolism in Bajra (Pennistum typhoides $\mathrm{S} \& \mathrm{H}$ ) leaves under $\mathrm{NaCl}$ salinity. Photosynthesis, 20: 50-55.

[45] Schapendonk, A.H.; Dolstra, O. and Van Kooten, O. (1989). The use of chlorophyll fluorescence as a screening method for cold tolerance in maize. Photosynthesis Research, 20: 235-247.

[46] Schreiber, U. and Bilger, W. (1987). Rapid assessment of stress effects on plant leaves by chlorophyll fluorescence measurements. In: Tenhunen, J.D., Catarino, F.M., Lange, O.L., Oechel, W.C. (Eds.), Plant Response to Stress-Functional Analysis in Mediterranean Ecosystems. NATO Advanced Science Institute Series. Springer-Verlag, Berlin, Heidelberg, New York, pp.27-53.

[47] Schreiber, U.; Bilger, W.; Hormann, H. and Neubauer, C. (1998). Chlorophyll fluorescence as a diagnostic tool: basics and some aspects of practical relevance. In: Ragavendra, A.S. (Ed.), Photosynthesis: A Comprehensive Treatise. Cambridge University Press, Cambridge, pp.320-336.

[48] Smillie, R.M.; Nott, R.; Hetherington, S.E. and Öquist, G. (1987). Chilling injury and recovery in detached and attached leaves measured by chlorophyll fluorescence. Physiol. Plant., 69: 419-428.

[49] Snedecor, G.W. and Cochran, W.G. (1980). Statistical Methods.7th Ed., Iowa state press, Ames, IA, USA.pp.401-403.

[50] Solecka, D.; Boudet, A.M. and Kacperska, A. (1999). Phenylpropanoid and anthocyanin changes in low-temperature treated winter oilseed rape leaves. Plant Physiol. Biochem., 37: 491-496.

[51] Van Kooten, O. and Snel, J.F.H. (1990). The use of chlorophyll fluorescence nomenclature in plant stress physiology. Photosynth. Res., 25:147-150.

[52] Van Kooten, O.; Mensink, M.G.J.; Otma, E.C.; Van Schaik, A.C.R. and Schouten, S.P. (1992). Chilling damage of dark stored cucumbers (CucumissativusL.) affects the maximum quantum yield of photosystem 2. In: Murata, N. (Ed.), Progress in Photosynthesis Research, Vol. 4. Kluwer, Dordrecht, pp.161-164.

[53] Wise, R. R. and Naylor, A. W. (1987). Chilling-enhanced photooxidation. Evidence for the role of singlet oxygen and superoxide in the breakdown of pigments and endogenous antioxidants. Plant Physiol., 83:278-282.

[54] Yamane, Y.; Shikanai, T.; Kashino, Y.; Koike, H. and Satoh, K. (2000). Reduction of QA in the dark: Another cause of fluorescence Foincreases by high temperatures in higher plants. Photosynthesis Res., 63: 23-34. 